\title{
A Scandinavian "Magna Charta"? \\ The Scandinavian Corps and the politics of memory \\ in South Africa (1899-1927)
}

\section{Christian Gerdov*}

\begin{abstract}
This article examines how the Scandinavian Corps, which fought on the Boer side for a brief period during the South African War (1899-1902) and participated in the battle of Magersfontein on 11 December 1899, was remembered and commemorated in South Africa from 1899 to 1927. Initially, most of the Scandinavian people resident in South Africa were opposed to the corps, and the erection of a monument in its honour met with little interest among them. However, at the unveiling ceremony of the first monument the memory of the corps resonated with the post-war narrative of brotherhood and unity between Boer and Briton in South Africa. In the 1920s the memory of the corps was revived among Scandinavian people, particularly through the magazine Fram (Forward), and commemorative events were held on the occasion of the 25th anniversary of the battle. A new monument was later erected and unveiled in 1927, and the same narrative of brotherhood and reconciliation dominated yet again. Through the memory of the corps, the Scandinavian population legitimised their place in the country and became dedicated South Africans. But as they became fully integrated into white South African society, the memory of the Scandinavian Corps appears to have faded.
\end{abstract}

Keywords: Scandinavian Corps, South Africa; brotherhood; commemoration; memory; monument; identity; race.

\section{Opsomming}

Hierdie artikel stel ondersoek in na die wyse waarop die Skandinawiese Korps, wat vir 'n kort tydjie aan die Boere se kant in die Suid-Afrikaanse Oorlog (1899-1902) geveg het, en ook aan die Slag van Magersfontein op 11 Desember 1899 deelgeneem het, vanaf 1899 tot 1927 in Suid-Afrika onthou en herdenk is. Aanvanklik was die meeste Skandinawiërs wat in Suid-Afrika woonagtig was gekant teen die korps, en die

* In 2016 I graduated with a Master of Arts degree, majoring in History, from the University of Gothenburg. This article is based in part on my MA dissertation which is entitled “'De kunde icke vika, blott falla kunde de': Historiebruket om den Skandinaviska Kåren och Slaget vid Magersfontein i Sverige, 1899-2015”. It examines how the Scandinavian Corps and its participation in the battle of Magersfontein, was remembered and commemorated in Sweden from 1899 until 2015.

How to cite this article: C. Gerdov, "A Scandinavian 'Magna Charta'? The Scandinavian Corps and the politics of memory in South Africa (1899-1927), Historia 61, 2, November 2016, pp 54-78. 
oprigting van 'n monument om hulle te vereer het weinig belangstelling uitgelok. Die eerste monument se onthullingseremonie het egter aanklank gevind by die naoorlogse narratief van eenheid en broederskap tussen Boer en Brit in Suid-Afrika. In die 1920's het die korps se nagedagtenis onder Skandinawiërs herleef, vernaam deur die tydskrif Fram (Voorwaarts), sowel as die gedenkfeeste wat tydens die 25ste herdenking van die slag gehou is. 'n Nuwe monument is later opgerig en in 1927 onthul, en dieselfde narratief van broederskap en versoening het weereens die botoon gevoer. Deur middel van die korps se nagedagtenis het die Skandinawiese bevolking sy plek in die land gelegitimeer en sodoende toegewyde Suid-Afrikaners geword. Namate hulle egter ten volle in die wit Suid-Afrikaanse samelewing opgegaan het, het die Skandinawiese Korps se nagedagtenis klaarblyklik ook vervaag.

Sleutelwoorde: Skandinawiese Korps; Suid-Afrika; broederskap; nagedagtenis; herdenking; monument; identiteit; ras.

Among the many monuments commemorating the fallen soldiers of the South African War (1899-1902), there are two at Magersfontein which are dedicated to the Scandinavian Corps that fought on the Boer side during the war, and its members who fell in battle on 11 December 1899. Here the word Scandinavian refers to the four nationalities who formed the main part of the corps, namely Swedes, Danes, Finns, and Norwegians, although the corps also included a smaller group of nonScandinavian members. ${ }^{1}$ Some 50 members of the Scandinavian Corps had been positioned at a picket near Magersfontein. Less than half of them died, either during the battle or as a result of their injuries. A few managed to escape back to the Boer lines, but the rest were taken as prisoners of war by the British. ${ }^{2}$ The remainder of the corps continued to fight alongside the Boers, but these men were captured in February of the following year, when general Piet Cronjé surrendered at Paardeberg.

This article discusses how the Scandinavian Corps was remembered and commemorated in South Africa from 1899 to 1927. It focuses on the two monuments, their unveiling ceremonies and the commemorative events held in honour of the corps, as well as the 25th anniversary of the battle of Magersfontein. Although Erlend Eidsvik has also written on this subject, and argues that the memory of the Scandinavian Corps was used during the 1920s to reinforce a sense of panScandinavian sentiment among the Scandinavian migrants in South Africa, his description of the corps and his analysis of the commemorative events held after the

1. Finns were, however, not always perceived as Scandinavians.

2. The primary sources differ on the exact number of men who were stationed at the outpost, and how many managed to retreat. For example, see "Hos en Svensk Krigsfånge”, Dagens Nyheter, 20 February 1900; “Den Skandinaviska Kåren”, Dagens Nyheter, 9 May 1900; "Den Skandinaviska Kåren i Boerkriget: Löjtnant Stålberg Berättar”, Dagens Nyheter, 19 August 1901; and "Bland Boerna”, Sydsvenska Dagbladet Snällposten, 28 July 1901. 
war years, is somewhat flawed. ${ }^{3}$ By ignoring the period prior to 1914, Eidsvik does not, for example, consider how the Scandinavians who were resident in South Africa viewed the Scandinavian Corps from the outset, nor does he discuss the earlier initiative of erecting a monument at Magersfontein in honour of the corps. Furthermore, by not analysing the two monuments or the unveiling ceremonies, he fails to situate the commemoration in the wider context of post-war memory politics in South Africa. In other words, how the commemoration of the corps became closely intertwined with the commemoration of the war in South Africa. In addition, one should also compare how the corps was commemorated in the Nordic region, because this reveals certain striking similarities with the South African case. These different perspectives are necessary to fully understand the questions of why the Scandinavian Corps was remembered and commemorated in South Africa, and what significance the memory of the corps held.

The article is structured chronologically in order to show the changes over time in the commemoration of the Scandinavian Corps. The first part gives a brief introduction to the history of the Scandinavian population in South Africa and the Scandinavian Corps. The second deals with the project of erecting the first monument in honour of the corps and its unveiling in 1908. Then the discussion turns to the commemorative events held in 1924 in honour of the 25th anniversary of the battle at Magersfontein. The next part revolves around the project of erecting a second monument in honour of the Scandinavian Corps, and its unveiling in 1927. The importance of race and the question of identity are then discussed, and finally, the findings of the article are summarised.

\section{Scandinavians and the South African War}

The influx of Scandinavian immigrants into South Africa peaked during the 1890s and around 1900 , as the war gained momentum. Their views concerning the warring parties were, according to the historian Arne Gunnar Carlsson, largely shaped by their place of residence. Those who had settled in the Boer republics tended to sympathise with the Boers, while those who had taken up residence in the British colonies often supported the British. However, this tends to be a rather simplistic explanation because it does not account for those who decided to remain neutral. Nor, as

3. For example, Eidsvik writes, “... the volunteers who joined the Scandinavian Corps were fighting a perceived aristocratic opposite, which also related to the political awakening of Norway" (i.e. Norway's opposition against "aristocratic" Sweden, which governed Norway at the time). But this argument does not account for the fact that Swedes were in the majority in the corps and that some of them were aristocrats (two were barons). It is thus unlikely that they fought a "perceived aristocratic opposition". See E. Eidsvik, "Expressions of Pan-Scandinavian Sentiments in the Magazine Fram among Scandinavian Migrants in South Africa, 1914-54", in J. Harvard and P. Stadius (eds), Communicating the North: Media Structures and Images in the Making of the Nordic Region (Ashgate, Burlington, 2013); and E. Eidsvik, Spaces of Scandinavian Encounters in Colonial South Africa: Reconfiguring Colonial Discourses (University of Bergen Press, Bergen, 2013), p 43. 
Frederick Hale points out, does it explain that many Scandinavian residents in the Transvaal had not come to terms with their status as second-class citizens. ${ }^{4}$ However, it was in the Transvaal (the Zuid-Afrikaansche Republiek) that the Scandinavian Corps was founded, ${ }^{5}$ although Hale notes that it is well-nigh impossible to ascertain how many members there were in the corps from the outset, or how many new recruits enlisted later. Details such as this were not documented at any point, although most primary sources agree that the corps comprised more than 100 members and that 13 of these were non-Scandinavians. ${ }^{6}$

The Scandinavian Corps was largely met with distrust and even disdain by their fellow countrymen in South Africa, in part because the Scandinavians thought that the support for the Boers would damage the general reputation of Scandinavians living in the country and might impact negatively on the prospects of those who decided to remain neutral. ${ }^{7}$ According to Hale, well over a 100 Scandinavians held a

4. According to contemporary newspaper articles in Sweden, the majority of the Scandinavian population in Johannesburg sympathised with the British. See, "Två år i Transvaal", Svenska Dagbladet, 6 October 1899; "Skandinaverne i Sydafrika och Kriget”, Nya Dagligt Allehanda, 8 April 1902; A.G. Carlsson, “Norske Reaksjoner på Boerkrigen 1899-1902: En Analyse av Norske Advisers Holdninger og en Beskrivelse av Norsk Engasjement, Inkludert Nordmenn i Sør-Afrika", MA dissertation, University of Trondheim, 1978, pp 93-97; A.H. Winquist, Scandinavians and South Africa: Their Impact on the Cultural, Social and Economic Development of pre-1902 South Africa (Balkema, Cape Town, 1978), pp 162-173; F. Hale, "The Scandinavian Corps in the Second Anglo-Boer War", Historia, 45, 1 (200), pp 221-223.

5. The idea to form a corps was first raised at a meeting held in Johannesburg, which broke down due to a difference of opinion. Exactly when the corps was founded is uncertain. According to Winquist, Scandinavians and South Africa, it was in September, but according to the initiator behind the corps, Christer Uggla, the decision was made after the outbreak of the war (11 October 1899). Another member of the corps wrote that they were ready to set out by 5 October. See P. Nordmann (ed.), Boerer och Engelsmän: Skildringar ur det Sydafrikanska Kriget, 1899-1901. Av Österbottningarna Matts Gustavsson, Nils Viklund m.fl. Medlemmar av den Skandinaviska Kåren (Svenska Kolkskolans Vänner, Helsingfors, 1910), p 15; The Military Archives of Sweden (Krigsarkivet) (hereafter KrA), Skandinaviska kårens Arkiv (hereafter SKA): Volume 1, Promemoria Skandinaviska Organisationen i Transvaal samt dess förhållande till Skandinaviska kåren och dess Ambulans åren, 1899-1900; Winquist, Scandinavians and South Africa, p 162; Hale, "The Scandinavian Corps in the Second Anglo-Boer War", p 222.

6. KrA, Erland Mossberg Archive (hereafter EM): Volume 26, Bilaga (Annexure) D. I Slaget vid Magersfointen den 11 Dec 1899, Deltagande av den Skandinaviska Kåren; KrA, SKA: Volume 2, Örteckning över den Skandinaviska Kåren; KrA, SKA: Volume 1, Berättelse om Boerkriget och Skandinaviska Kåren av Erik Stålberg (1910), Unpublished manuscript; Hale, "The Scandinavian Corps in the Second Anglo-Boer War", p 224.

7. Some said Scandinavians were even dismissed by their British employers because of the support the Scandinavian Corps gave to the Boers. This caused them to lament: "We [Scandinavians] have become ill-famed and must now suffer the consequences thereof." See "Svenskarne i Transvaal", Svenska Dagbladet, 3 October 1900 (translated 
counter-meeting in Durban where they discredited the formation of the corps and "insisted that their ethnic fellows in Johannesburg and Pretoria [did] not represent the general sentiment of the Scandinavians in South Africa". ${ }^{8}$ Similar opinions were voiced by Scandinavians residing in Bloemfontein, one of whom, in a letter to a Swedish newspaper, wrote:

We thought it wisest to remain neutral, and all would probably have gone well had it not been for some of our fellow countrymen, who, for their own personal gain, offered their services to the Boer government. ... Cunningly, they used their influence over their fellow countrymen, and claiming they had no other interest than love for their newfound homeland ... they began their dirty work. They organised meetings where they painted the sufferings of the Boers under the English yoke in bright colours. These henchmen of the Boer government worked with a zeal worthy of a higher cause. ${ }^{9}$

Such harsh responses raise the question of why these immigrants, very few of whom had any military experience, nevertheless decided to join the Scandinavian Corps and to support the Boers. According to the initiator behind the corps, Christer Uggla, their decision to fight alongside the Boer forces was motivated by gratitude for the hospitality the Scandinavians had enjoyed in the two Boer republics. There were also members of the corps who later claimed that they had fought for what they believed to be a just and righteous cause. ${ }^{10}$ However, their motives were perhaps not entirely altruistic, because enlisting meant that members of the corps were entitled to attain citizenship of the Boer republics and this undoubtedly played an important part in the decision to join the corps. ${ }^{11}$ Furthermore, since most of them were unemployed there was also, as Winquist writes, “ ... the hope that if the Boers won, they would reap the benefits of being on the victorious side". ${ }^{12}$ Be that as it may,

by the author); and also Hale, "The Scandinavian Corps in the Second Anglo-Boer War", p 222.

8. Hale, "The Scandinavian Corps in the Second Anglo-Boer War", p 222.

9. "Svenskarne i Transvaal", Svenska Dagbladet, 3 October 1900 (translated by the author). A similar attitude was voiced by the Cape Town-based Norwegian-Swedish consul general (Norway was part of a union with Sweden from 1814 to 1905). He claimed that many members of the corps had either been lured or forced to join up. See "Vår Generalkonsul i Kap om Boerkriget", Svenska Dagbladet, 7 September 1901.

10. C. Uggla, Redogörelse över Magersfontein Minnesfesternas Ändamål och Resultat: 189911 Dec. 1924 (Almqvist \& Wiksell, Uppsala, 1926), p 5.

11. Some members did indeed attain "burgher papers" in accordance with Article 1442, in effect from 29 September 1899. These papers were signed in Pretoria on the 13 October 1899. How many of them received such papers is difficult to estimate, especially with regard to the new recruits. The lack of documentation makes it wellnigh impossible to ascertain. See KrA, SKA: Volume 3, EED (Burgher Papers Granting Citizenship).

12. Winquist, Scandinavians and South Africa, p 165. 
many members later denied any interest in such prospects, and opposed the notion that they were simply "mercenaries". ${ }^{13}$

The corps participated briefly in the siege of Mafeking (today known as Mahikeng) but made no great impact there and had already moved on before the siege came to an end. Instead it was at Magersfontein, near Kimberley, that their most memorable battle was fought. It was here that about 50 members of the corps were stationed at a picket, with two Boer commandos placed nearby, and they went into combat against the Scottish Highlanders on the morning of 11 December 1899. Initially, the Scottish Highlanders were surprised by the fire from the Scandinavians and suffered heavy losses. However, they soon regained their composure and managed to circumvent the Scandinavians' lines, whereupon the tables were turned. Eighteen Scandinavians died and only a few managed to retreat to the Boer lines where the other members of the corps are believed to have remained. The rest of those who had been stationed at the picket lay wounded and were soon captured by the British. Five of the wounded men later died from the injuries they had suffered in the battle. ${ }^{14}$

13. “Bland Boerna”, Sydsvenska Dagbladet Snällposten, 28 July 1901; KrA, SKA: Volume 1, Berättelse om Boerkriget och Skandinaviska Kåren av Erik Stålberg (1910), Unpublished manuscript; Carlsson, "Norske Reaksjoner på Boerkrigen, 1899-1902", pp 95-96; S.O. Eklund, "The Scandinavians and the Boer War", South Africa International, 10 (1980), pp 223-228; Hale, "The Scandinavian Corps in the Second Anglo-Boer War", p 225.

14. The total number of members of the Scandinavian Corps who perished at Magersfontein has often been exaggerated, usually because it includes those who died in combat at Paardeberg. This is why there are 28 names engraved on the cornerstones of the first monument, whereas only 23 died at Magersfontein. On this, see "Svenskarne i Kriget”, Göteborgs Handels- och Sjöfartstidning, 3 March 1900; "Hos en Svensk Krigsfånge", Dagens Nyheter, 20 February 1900; H.P. Janek, Bland Boer och Britter: Skildringar från Kriget i Sydafrika, 1898-1900: Med 16 Illustr. efter Fotografier (Schmidts Boktr., Helsingborg, 1901), pp 44-56; "Svenskarne i Boerkriget", Sydsvenska Dagbladet Snällposten, 6 March 1904; E. Stålberg, "Skandinaviska Kåren”, Vårt Försvar, (1904), pp 19-20. See also KrA, EM: Volume 25, Letter from Hjalmar Janek Petterson to Erland Mossberg, 23 August 1904; KrA, EM: Volume 25, Letter from A. Claudelin to Erland Mossberg, 4 September 1904; KrA, EM: Volume 26, Bilaga (Annexure), D.I. Slaget vid Magersfontein den 11. dec. 1899 Deltagande av den Skandinaviska Kåren; Nordmann (ed.), Boerer och Engelsmän, pp 34-36, 41-52 and 66; KrA, SKA: Volume 1, Berättelse om Boerkriget och Skandinaviska Kåren av Erik Stålberg (1910), Unpublished manuscript; H.E. Uddgren Hjältarna vid Magersfontein: en Skildring av den Skandinaviska Kårens och Ambulansens Öden och Äventyr [Minnesskrift] (Seelig, Stockholm, 1924), pp 43-48, 51-53, 86-89; Uggla, Redogörelse över Magersfontein, p 6; M. Uola, "Finnish Warriors in the South African War", Siirtolaisuus-Migration, 1 (1977), p 4; K.-G. Olin, Afrikafeber (Olimex, Jakobstad, 2000), p 93; Hale, "The Scandinavian Corps in the Second Anglo-Boer War", pp 229232; B. Nasson, The Boer War: The Struggle for South Africa (History Press, Stroud, 2011), p 144. 
Why were all the members of the Scandinavian Corps not stationed at the picket? And why did they not retreat when they were attacked by a much larger force? The answers to these questions remain unknown, although some have said that General Cronjé asked the Scandinavians to fall at their post if necessary, rather than retreat - an order which they appear to have obeyed to the letter. But this statement is contradicted by evidence that Cronjé did in fact issue the order to retreat, which instruction the Boer commandos nearby had duly followed. Furthermore, when Cronjé met the Scandinavian survivors later, he asked them why their fallen captain, Johannes Flygare, had disobeyed the order to fall back. According to the Finnish member, Niklas Viklund, Flygare had opposed any suggestion that his men should retreat. And the first lieutenant of the corps, Erik Stålberg, later claimed with great fervour that the order to retreat had not been given - and if it had been issued, it had certainly never been relayed to members of the corps. ${ }^{15}$

However, the Scandinavian Corps was not, as some have crudely put it, "completely annihilated" at Magersfontein. ${ }^{16}$ It was soon reinforced with new recruits, and the Scandinavians appointed a new captain, the Dane Jens Friis. They continued to fight under the name of the Scandinavian Corps and followed General Cronjé as he and his Boer forces moved on. But their journey was cut short because they were defeated and captured, together with the rest of Cronjé's men, when the old general eventually surrendered to the British at Paardeberg in February 1900. ${ }^{17}$ At the end of the war, when peace was declared, most of the Scandinavians returned home to their native countries. However, there were also those who returned to South Africa again after some years had passed. ${ }^{18}$

15. "Svenskarne i Kriget", Göteborgs Handels- och Sjöfartstidning, 3 March 1900; "Hos en Svensk Krigsfånge", Dagens Nyheter, 20 February 1900; Janek, Bland Boer och Britter, pp 44-56; "Svenskarne i Boerkriget", Sydsvenska Dagbladet Snällposten, 6 March 1904; Stålberg, pp 19-20; Nordmann (ed.), Boerer och Engelsmän, pp 34-36, 41-52 and 66; KrA, SKA: Volume 1, Berättelse om Boerkriget och Skandinaviska Kåren av Erik Stålberg (1910), Unpublished manuscript; Uddgren, Hjältarna vid Magersfontein, pp 43-48, 51-53, 86-89.

16. This rhetoric was particularly strong in the different subscription campaigns that were launched to fund the monuments and events commemorating the Scandinavian Corps. See for example KrA, EM: Bilaga A. Subskriptionslista, Volume 26, "The small corps (some fifty men) was hereby completely annihilated", (translated by the author]. See also KrA, SKA: Volume 3, Teckningslista.

17. Nordmann (ed.), Boerer och Engelsmän, pp 63-67, 72-93.

18. According to Viklund and the son of John Alfred Eklund (who fought in the corps), the POWs were able to remain in South Africa if they pledged allegiance to the British Crown, although most of them rejected the offer. Eklund's son later explained in an interview that some of the Scandinavians were expelled to the Netherlands, and that when Louis Botha visited that country he encouraged them to return to South Africa, which they later did. See KrA, EM: Bilaga A. Subskriptionslista; Nordmann (ed.), Boerer och Engelsmän, pp 88-92; Winquist, Scandinavians and South Africa, p 174; and "En Sten av Svensk Granit", Svenska Dagbladet, 19 June 1988. 


\section{A monumental task (part one)}

In 1901, when members of the Scandinavian corps were still being held as prisoners of war on St Helena and in Ceylon, a committee comprising a small group of Scandinavians was formed in Kimberley. The committee's sole purpose was to erect a monument commemorating the Scandinavian Corps and those members who fell during the battle at Magersfontein in 1899. According to Lieutenant Erland Mossberg, who served as a Swedish military attaché in the British Army during the South African War, he was approached by this committee. He was asked to seek support in Scandinavia for the proposed project. Mossberg agreed and pledged to work tirelessly to achieve this goal. Later, when he returned to Sweden he founded the Centralkommittén för Minnesvårdens Resande (Central Committee for Erecting the Memorial) in Stockholm together with Colonel F.I. von Heland and his friend Harald Sohlman, who was the chief editor of the Swedish newspaper Aftonbladet. ${ }^{19}$

In 1902, Mossberg received a letter from the Kimberley Committee, in which it elaborated on ideas for the design of the monument. They wanted an "allnordiskt" (all-Nordic) monument, comprising a bautasten ${ }^{20}$ (a type of monolith) that was to be surrounded by four cornerstones engraved with symbolic shieldmaidens/Valkyries; ${ }^{21}$ the names of the fallen; and the names of the four Scandinavian countries in the corps, namely Svea (Sweden); Nora (Norway), Dana (Denmark) and Suomi (Finland). Accordingly, the monument is inscribed with historic symbols and names that allude to a shared common past (that is, the Vikings). This symbolised the fusion of the four Scandinavian countries into one imagined whole.22 During the spring of 1903, the Kimberley Committee's proposal was published in the Scandinavian newspapers. A plea was issued to the patriotic men and women in Scandinavia for support -

19. KrA, EM: Volume 26, Redogörelse för Tillkomsten av Skandinavmonumentet vid Magersfontein; E. Mossberg, Minnen Från Tre Krig och Från Krig i Fred (Bonnier, Stockholm, 1943), pp 17-20.

20. A bautasten is a type of Viking memorial, but in the case of the bautasten erected in honour of the Scandinavian Corps, because it is engraved it is strictly speaking not a true bautasten. See B. Meijer (ed.), Nordisk Familjebok: Konversations Lexikon och Realencyklopedi (Nordisk Familjeboks Förlag, Stockholm, 1904), pp 1095-1096.

21. Shieldmaidens (in Swedish: sköldmö) often appear in Scandinavian folklore, and old Viking sagas, as warrior women. The shieldmaiden inspired the belief in the Valkyries, which were mythological beings believed to be present on the battlefield to transport the slain heroes to Valhalla, the hall of Odin. According to Näsström, Valkyrie literally means "those who select the slain". See B-M. Näsström, Nordiska Gudinnor: Nytolkningar av den Förkristna Mytologin (Bonnier, Stockholm, 2009), p 157; and T. Westrin (ed.), Nordisk Familjebok: Konversations Lexikon och Realencyklopedi (Nordisk Familjeboks Förlag, Stockholm, 1917), pp 1371-1372.

22. KrA, EM: Volume 25, Letter from A.W. Dahm to Erland Mossberg, 1 November 1902; "De Skandinaviska Hjältarna vid Magersfontein. En Minnesvård bör Resas", Aftonbladet, 24 April 1903; "Ett Förslag till Monument", Göteborgs Handels- och Sjöfartstidning, 25 April 1903; "De Skandinaviska Hjältarna vid Magersfontein: Upprop för Insamling till Minnesvärd”, Aftonbladet, 6 June 1903. 
especially since it appears that the committee had failed to gain the support of fellow Scandinavians in South Africa, or as they themselves explained:

Cordial invitations were sent to affluent Scandinavians in the Cape Colony and in Natal, asking for their support for the project - both financially and in an advisory capacity. Alas, although they gracefully accepted the invitation, they chose to oppose rather than to support the [Kimberley] Committee's endeavours to erect a memorial for those who had perished. ${ }^{23}$

A similar remark about the apparent disinterest among Scandinavians resident in South Africa to join the campaign to erect a monument in commemoration of the Scandinavian Corps was also voiced by a former member of the corps, Hjalmar Janek Petterson. In a private letter to Mossberg he stated with unconcealed bitterness:

\begin{abstract}
I heard from my African friend that the committee in South Africa had difficulty collecting anything, in part because of pressure from the English. He [told me that he] dared not support the project, because his [English] employer had said outright that those who signed it would "hurt our feelings". Indeed, most Scandinavians have now attached themselves to the Englishmen, which should be respected because the risk of starving to death has thereby been lessened somewhat. However, this does not explain why next to nothing has been collected in the Transvaal, where, in the past, a $£ 5$ note easily went to less honourable ends. 24
\end{abstract}

Thus, the work of Mossberg and the Central Committee proved invaluable for the realisation of the project. Indeed, it was not contributions raised within South Africa but rather those from the Scandinavian countries which funded the monument, a fact which Eidsvik fails to mention. Sweden contributed most of the money, and the bulk of the contributions came from the Swedish army. Indeed, Magersfontein was commonly hailed as a testament to the Swedish (and Scandinavian) martial spirit, and the battle was even mentioned as a classic example of great courage and endurance in the instruction booklets that were handed out to all soldiers in the Swedish army. ${ }^{25}$ This narrative was in the same idiom as the praise surrounding the Scottish monument, commemorating those brave Highlanders who had fought against the Scandinavian Corps and perished in the battle at Magersfontein. The inscription of

23. "De Skandinaviska Hjältarna vid Magersfontein. En Minnesvård bör Resas”, (translated by the author), Aftonbladet, 24 April 1903.

24. KrA, EM: Volume 25, Letter from Hjalmar Janek Petterson to Erland Mossberg, 19 November 1904 (translated by the author).

25. Undervisning för Infanteristen, Stockholm, mentioned in every edition from 1904 to 1917; KrA, EM: Volume 26, Redogörelse för Tillkomsten av Skandinavmonumentet vid Magersfontein; KrA, EM: Volume 26, Bilaga A. Subskriptionslista; Mossberg, Minnen Från Tre Krig och Från Krig i Fred, p 95. 
this monument reads: "Scotland is poorer in men, but richer in heroes", as Elaine McFarland shows. ${ }^{26}$

The corps had captured the hearts and minds of the Swedes, and as early as October 1904, the bautasten and the Swedish cornerstone (both of which Sweden paid for) were sent off to South Africa. The idea was to ship the remaining parts before the end of the year, but the project was delayed - partly because of a slower rate of contributions in Norway and Denmark (each participating country was supposed to fund its own cornerstone). ${ }^{27}$ In 1907, when at last all the pieces of the monument had arrived in South Africa, new difficulties arose because the Kimberley Committee, lacked sufficient funds to transport the monument to its destination at the Magersfontein site. This infuriated Mossberg who later claimed to have paid for the monument "all by myself" - which is improbable due to its high cost. It was most likely financed through a new subscription campaign. ${ }^{28}$ When the monument was erected it was not, as originally planned, placed on the site of the Scandinavians' graves because the owner of the land opposed this suggestion. It was eventually placed on a hill some five kilometres away. ${ }^{29}$

26. E.W. McFarland, "Commemoration of the South African War in Scotland, 1900-10", The Scottish Historical Review, 89, 2(October 2010), pp 194-223 at p 195.

27. Finland's cornerstone had already been paid for by a company in Helsingfors, but was delayed nonetheless. See KrA, EM: Volume 25, "Insamlingar Till en Vård öfver de vid Magersfontein Stupade Skandinaverna.", Unidentified newspaper dated 16 November 1903; "Skandinavmonumentet vid Magersfontein", Aftonbladet, 19 January 1904; "Skandinavmonumentet vid Magersfontein", Aftonbladet, 12 November 1904; KrA, EM: Volume 25, Letter from K. Damm to Erland Mossberg, 11 November 1904; KrA, EM: Volume 25, Letter from K. Damm to Erland Mossberg, 4 May 1905; "Det Skandinaviska Magersfontein Monumentets Öde", Aftonbladet, 3 November 1906. See also Riksarkivet, Swedish State Archives (hereafter RA), Utrikesdepartementet 1902 års Dossiersystem 1748-1920 (hereafter UD 1748-1920), Volume 2456, Dossier 31, File D, 19, Telegram from the Swedish Consul-General in Cape Town to the Swedish Minister of Foreign Affairs, 17 December 1907; and KrA, EM: Volume 26, Redogörelse för Tillkomsten av Skandinavmonumentet vid Magersfontein.

28. The Swedish consul-general in Cape Town also provided assistance and managed to reduce custom fees and transport costs. See RA, UD 1748-1920, Volume 2456, Dossier 31, File D,19, Telegram from the Swedish Consul-General in Cape Town to the Swedish Minister of Foreign Affairs, 17 December 1907. See KrA, EM: Volume 25, Janek Petterson's call for contributions, “Upprop! Minnesvården vid Magersfontein”; and KrA, EM: Volume 26, Letter from E. Mossberg to Carl Gustaf "Gösta” Drake, 16 January 1939.

29. It was said that the owner of the land was a Scot who opposed the Kimberley Committee's request to erect the monument at the gravesites because of his hatred of the Scandinavians who had fought his fellow countrymen, the Scottish Highlanders. See "Det Skandinaviska Magersfontein Monumentets Öde", Aftonbladet, 3 November 1906; and KrA, SKA: Volume 3, De Skandinaviska Gravarna vid Magersfontein. 


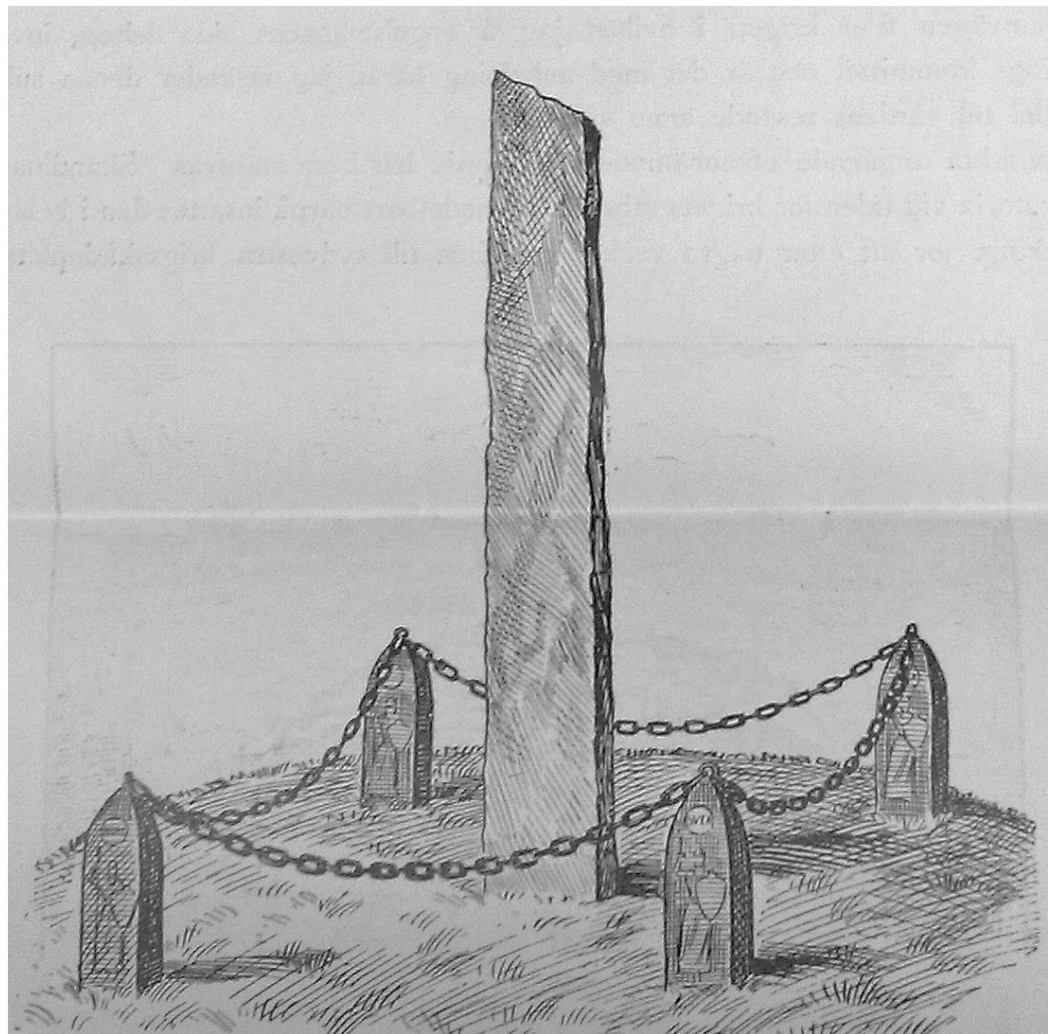

Figure 1: A sketch of the proposed monument to be erected at Magersfontein, comprising a bautasten (monolith) surrounded by four cornerstones, engraved with shieldmaidens and the names of the fallen. The sketch was part of the subscription campaign in 1903/04 in Sweden. Later, the bautasten were engraved with name of the battlefield and the date of the battle.

Source: Military Archives of Sweden, Erland Mossberg Collection, Volume 26.

The Kimberley Committee wanted the Swedish consul-general in Cape Town to officiate at the unveiling ceremony (together with the other Scandinavian consuls), thereby formalising the event. They also wanted a member of the Afrikaner elite, former Boer generals, such as Louis Botha or Christiaan de Wet (or even the former president of the Orange Free State, Marthinus Steyn) to unveil the monument. However, in telegrams to the Swedish minister of foreign affairs, the Swedish consul remarked that it would be politically unwise for him to attend because his presence might be perceived as a political statement (in support of the Boer cause) which 
would in turn be detrimental to Swedish interests in South Africa. ${ }^{30}$ Therefore he decided, together with the other Scandinavian consuls, that it would be best if none of them attended (an agreement which the Danish consul, Ferdinand von Prior, would later break). The absence of the Swedish consul-general angered the Kimberley Committee, and prompted them to send a letter of complaint to the Swedish minister of foreign affairs about the incident. ${ }^{31}$

Despite these disagreements the unveiling ceremony went ahead as planned because Louis Botha, the current prime minister of the Transvaal Colony, unveiled the monument flanked by his attorney general, J.B.M. Hertzog. Most attendees appear to have been Afrikaners, while some English speakers and a number of Scandinavian migrants were also present at the ceremony. The presence of Botha, Hertzog and a crowd of Afrikaners highlight the political significance ascribed to the monument indeed, it had clearly not been erected exclusively for the Scandinavians. The speeches presented during the ceremony underscore this important point. ${ }^{32}$

The unveiling ceremony began with a speech delivered by the Danish consul, von Prior, who strongly emphasised that the commemoration of the Scandinavian Corps was not an issue of choosing sides; it was to commemorate the courage and valour they had shown, proving "themselves to be true descendants of valiant races". ${ }^{33}$ Furthermore, von Prior claimed that even though the corps had used the name Scandinavian, its members had nonetheless been true "burghers" - a statement that was met with loud applause. And later, in a similar manner, Hertzog declared that the Scandinavians had embraced South Africa as their new homeland, and because they had fought and fallen in its name they should be hailed as true sons of

30. RA, UD 1748-1920, Volume 2456, Dossier 31, File D,19, Telegram from the Swedish Consul-General in Cape Town to the Swedish Minister of Foreign Affairs, 17 December 1907.

31. RA, UD 1748-1920, Volume 2456, Dossier 31, File D, 19, Telegram from the Swedish Consul-General in Cape Town to the Swedish Minister of Foreign Affairs, 17 December 1907; RA, UD 1748-1920, Volume 2456, Dossier 31, File D, 19, Telegram from the Swedish Consul-General in Cape Town to the Swedish Minister of Foreign Affairs, 18 December 1907; RA, UD 1748-1920, Volume 2456, Dossier 31, File D, 19, Telegram from Swedish Consul-General in Cape Town to Swedish Minister of Foreign Affairs, 24 December 1907; RA, UD 1748-1920, Volume 2456, Dossier 31, File D, 19, Telegram from Swedish Consul-General in Cape Town to the Swedish Minister of Foreign Affairs, 20 January 1908.; RA, UD 1748-1920, Volume 2456, Dossier 31, File D, 19, Letter from A.W. Dahm to the Swedish Royal Department of Foreign Affairs, 22 June 1908.

32. “A Scandinavian Memorial”, The Cape Times, 27 April 1908; "Magersfontein Scandinavian Memorial”, The Diamond Fields Advertiser, 27 April 1908. See also RA, UD 1748-1920, Volume 2456, Dossier 31, File D, 19, Telegram from the Swedish Consul-General in Cape Town to the Swedish Minister of Foreign Affairs, 29 April 1908; and Telegram from the Swedish Consul-General in Cape Town to the Swedish Minister of Foreign Affairs, no. 82, 1908.

33. "Magersfontein: Scandinavian Memorial", The Diamond Fields Advertiser, 27 April 1908. 
South Africa - all of which was again met with enthusiastic applause..$^{34}$

After von Prior's speech, the monument was unveiled by Botha, and then followed the national anthems of the Scandinavian countries, after which Botha gave his address, a speech in which he shared von Prior's view that they had gathered to commemorate and admire those brave men who had upheld the traditions of their forefathers, and furthermore, that their sacrifice would forever be treasured in the history of South Africa. Botha then proclaimed that the period of strife had passed, and instead, the time had come for the white races to work together because "the blood of the different races has flowed together here, so the different white races in South Africa will unite to form one great whole". ${ }^{35}$ This sentiment was then reiterated by Hertzog who issued a plea for "the union of the white races of South Africa". ${ }^{36}$

The commemoration of the Scandinavian Corps can therefore be situated in a larger context of post-war memory politics in South Africa. In a way, the Scandinavian Corps, and the commemoration of their bravery, became the backdrop in a production about Boer and Briton seeking common ground. As Bill Nasson has pointed out, after the war came to an end, several of the old Afrikaner leaders sought a pragmatic and reconciliatory approach in order to forge "an inclusive white Afrikaner-English political nation", much to the chagrin of the bittereinders (bitterenders) of the South African War. ${ }^{37}$ This approach was clearly seized upon by Botha and Hertzog during the unveiling ceremony, when they pleaded for reconciliation and cooperation between Boer and Briton. Friendship and brotherhood was the path to unity and a prosperous future - that was their message. Or as Botha put it : "Do not let us forget that there is peace today in South Africa, and that this must continue into the future." 38 In a manner of speaking, the Scandinavians merely played the part of extras.

\section{Commemorating the 25 th anniversary}

After the unveiling ceremony in 1908, the memory of the Scandinavian Corps seems to have faded somewhat, not only in South Africa but in Scandinavia as well. The 10th anniversary of the battle at Magersfontein was, for example, only mentioned briefly in some Swedish newspapers in 1909. However, during the 1920s this was all destined to change and an initiative was launched to remember the bravery of the Scandinavian Corps and the 25th anniversary of the battle at Magersfontein, with

34. "Magersfontein: Scandinavian Memorial", The Diamond Fields Advertiser, 27 April 1908.

35. "Magersfontein: Scandinavian Memorial", The Diamond Fields Advertiser, 27 April 1908.

36. "A True Peace", The South African News, 27 April 1908.

37. B. Nasson, "The South African War/Anglo-Boer War, 1899-1902 and Political Memory in South Africa", in T.G. Ashplant, G. Dawson and M. Roper (eds), Commemorating War: The Politics of Memory (Transaction Publishers, New Brunswick, 2004), p 111.

38. "Magersfontein: Scandinavian Memorial", The Diamond Fields Advertiser, 27 April 1908. 
commemorative events in the four Scandinavian capitals (Stockholm, Oslo, Copenhagen and Helsinki). Uggla, the figure behind the formation of the Scandinavian Corps, together with Major General K.O. Toll and Colonel G. Lindström, founded a new Central Committee in Stockholm, tasked with gathering funds for the proposed commemorative events. ${ }^{39}$ According to the committee, its aim was :

... to commemorate the memory of these brave sons of the north and their proud feat, and furthermore to promote the Scandinavian feeling of unity, which is so clearly symbolised by the iron chains that unite the monument's four cornerstones. ${ }^{40}$

Pan-Scandinavian expression was thus integral to the commemorations held in Scandinavia. In South Africa, where such events were also held in Durban, Johannesburg and Kimberley, the purpose of commemorating the 25th anniversary of the battle and the bravery of the Scandinavian Corps served a similar purpose, albeit with some important exceptions and additions. Here the organiser was the Norwegian Thoralf Ericsen, who was described in Fram as "a good Scandinavian, but also a pure-blooded South African". ${ }^{41}$ In Kimberley the commemoration was held at the Scandinavian monument, and much like the unveiling ceremony in 1908, it was not only Scandinavians who attended (or rather participated) but some English speakers and a number of Afrikaners, including a prominent guest, F.W. Reitz, who at the time was a senator of the Union government. As was the case in 1908, the theme of the event was reconciliation, which was also voiced at the ceremonies held in Durban and in Johannesburg. ${ }^{42}$ In a telegram that was read out during the commemoration in Kimberley, written by the engineer Anton G. Høyer, who was also the founder of the magazine Fram ${ }^{43}$ there was an emotive poem on the same theme. It read:

As heroes true to the land where they live

May friend and foe forget and forgive

As may we in place for South Africas [sic] land

As they gave their lives, let us give what we can. ${ }^{44}$

39. Fram, Norks Maanedsblad for Skandinaver i Syd-Afrika, den Norske Forening, Durban, "Magersfontein Nummer" (hereafter Fram), 131 (February 1925); KrA, SKA: Volume 3, Teckningslista.

40. KrA, SKA: Volume 3, Teckningslista (translated by the author). In Uggla's speech at the commemorative event in Stockholm, he also emphasised the need to build Scandinavian unity. See KrA, SKA: Volume 3, Tolkning av Skandinaviska Magersfontein-monumentet i Sydafrika; and "Magersfontein-minnet Högtidligt Firat", Aftonbladet, 12 December 1924

41. Fram, "Magersfontein Nummer", February 1925, p 15 (translated by the author).

42. Fram, "Magersfontein Nummer", February 1925, pp 6-10.

43. Eidsvik, "Expressions of Pan-Scandinavian Sentiment", p 130.

44. Fram, "Magersfontein Nummer", February 1925, p 6. 
However, Høyer's participation in the commemoration of the Scandinavian corps is somewhat ironic in the light of the fact that he had vilified the formation of corps back in $1899 .{ }^{45}$

The magazine Fram was founded in 1914 and throughout its existence, as Eidsvik writes, "repeated efforts were made to promote the idea of a shared Scandinavian legacy and the vision of a pan-Scandinavian community in South Africa". ${ }^{46}$ This idea was anchored and legitimised through the commemoration of the Scandinavian Corps, at least according to Eidsvik.

However, when looking carefully at these commemorative events in South Africa, one comes to the conclusion that pan-Scandinavian sentiment only played a minor part. Instead, the commemoration of the Scandinavian Corps was once again situated in the wider context of the two white races of South Africa, Afrikaner and those of British extraction, coming together and forming a greater whole. The core meaning of the commemoration of the corps was that the sacrifices made during the South African War had not been in vain, for out of the war a united South Africa had evolved. As the Reverend J.E. Norenius put it at the commemoration held in Johannesburg: "Was all the blood that was spilt during the long war and all the suffering, to no avail? Our answer is no. For out of the bitter fight the united South Africa has come forth". ${ }^{4}$

The importance of white racial unity thus trumped the significance of promoting pan-Scandinavian sentiment in South Africa, and pan-Scandinavian sentiment (which was showcased during these commemorative events) was arguably much stronger in Scandinavia than in South Africa. Pan-Scandinavianism was, after all, quite literally one of the main aims of these commemorative events and was also considered one of its greatest achievements - at least according to Uggla, who during the commemorative event in Stockholm called for the preservation of the "Magersfontein spirit", in other words, the continuation of the brotherhood and feeling of togetherness between the various Scandinavian peoples, which was exemplified in the Scandinavian Corps. ${ }^{48}$

\section{A monumental task (part two)}

The idea of erecting a new monument, which would be placed at the site of the Scandinavians' graves, was first raised by Uggla during the commemoration held in Stockholm on 11 December 1924. The suggestion appears to have garnered great interest. The monument was unveiled at Magersfontein on 16 December 1927, but it was erected on the site some months earlier, in the spring. The monument comprises two crosses raised on wide cairns, thus merging Viking and Christian symbolism.

45. Hale, "The Scandinavian Corps in the Second Anglo-Boer War", pp 223-224.

46. Eidsvik, "Expressions of Pan-Scandinavian Sentiment", p 123.

47. Fram, "Magersfontein Nummer", February 1925, p 8, (translated by the author).

48. Uggla, Redogörelse över Magersfontein. 
Although this time around, some contributions came from the Scandinavian population who lived in South Africa, yet again people in Sweden were the main contributors (which Eidsvik again fails to notice). And much like the previous monument, it was transported from Scandinavia to South Africa. ${ }^{49}$

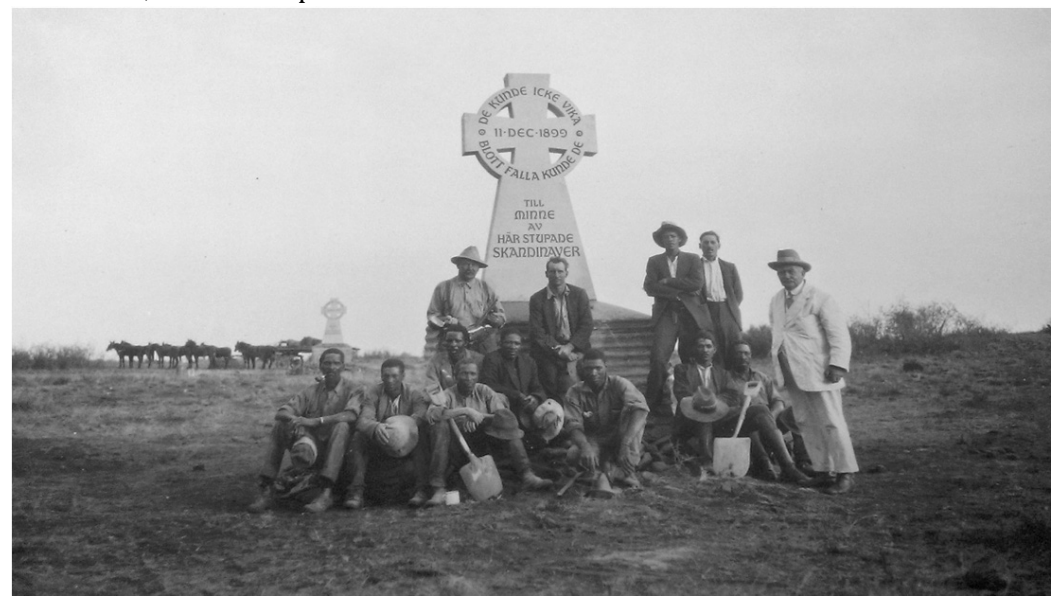

Figure 2: "Waldemar Crosses Erected", a photograph taken after the monuments in memory of the Scandinavian Corps were erected (the second cross can be seen in the background). Source: Military Archives of Sweden, Archive of the Scandinavian Corps, Volume 3.

The Swedish consul-general in Cape Town was asked, as he had been in 1907, if he would officiate at the unveiling ceremony, but once again he declined (although this time his actions aroused some criticism in Sweden). Further mirroring the unveiling ceremony in 1908, an Afrikaner, J.C. Smuts, a former prime minister of the Union of South Africa and a Boer general in the South African War, was tasked with unveiling the monument. However, this time around the national anthems of the Scandinavian countries were absent - which, according to Fram, was because there were so few Scandinavians present (a tenuous argument because the same had been true at the unveiling ceremony in 1908). And once again, most of those who attended the ceremony in1927 appear to have been Afrikaners. ${ }^{50}$

49. KrA, SKA: Volume 3, De Skandinaviska Gravarna vid Magersfontein; KrA, SKA: Volume 3, Letter from Christer Uggla to the Swedish Minister of Foreign Affairs, 20 October 1927; “Hjältegravarna i Magersfontein”, Aftonbladet, 14 December 1926; “Magersfontein Monumentet Avtäckes i Morgon”, Aftonbladet, 23 April 1927; "Grantikorsen vid Magersfontein Avtäckas", Svenska Dagbladet, 23 April 1927; "Korsen vid Magersfontein Avtäckta", Hufvudstadsbladet 26 April 1927; and Eidsvik, "Expressions of Pan-Scandinavian Sentiment", p 138.

50. Fram, "Special Magersfontein Number", February 1928, pp 6, 14-19; KrA, SKA: Volume 3, Unveiling of the Tombstones on the Scandinavian Graves at Magersfontein; KrA, SKA: Volume 3, Copy of a letter sent from T. Ericsen to H. Rosenlund, the ConsulGeneral, 18 March 1927; KrA, SKA: Volume 3. Letter from Thoralf Ericsen to Christer 
In his speech, which was almost a carbon copy of Botha's in 1908, Smuts emphasised the importance of brotherhood and unity, where the white people would work together in unison for a better South Africa - only then would the sacrifice of those who fell during the South African War not have been in vain. ${ }^{51}$ The South African War was, in Smuts's eyes, seen "as a stepping stone to a great future". ${ }^{22}$ This sentiment was also reiterated by the other speakers, for example in Ds. J.R. Albertyn's fervent prayer:

Furthermore, we thank you that here, where Boer and Brit were locked in a battle to the death 28 years ago, so many representatives of both races can meet each other today in a spirit of friendship and brotherhood. In the past few years, God has brought about a better understanding; mutual respect and cooperation for the good of our fatherland has flowered after hatred and misunderstanding. Let our togetherness on this day contribute to strengthening the spirit of accommodation, and to inspire each to heartfelt and earnest efforts for the sake of the country we all hold dear. ${ }^{53}$

In this sense, the war was believed to have laid the foundation for a united South Africa, where Boer and Briton could meet each other in the spirit of friendship and brotherhood. Unity was key, and the government was entrusted with administering this great inheritance. At a speech presented at the luncheon hosted after the unveiling ceremony, Sir David Harris implored: “... let bygones be bygones", and he went on to say that those who still bore grudges in their hearts and voiced their bitter expressions in the newspapers were "from the mouths of a small minority of irreconcilibles [sic] who do not count ...".54 Once again, the commemoration of the Scandinavian Corps was situated in the wider context of post-war memory politics in South Africa, although the Scandinavians now took centre stage. In addressing the Scandinavians (those few who attended the ceremony), Smuts said: "I hope you are with us in that you are good South Africans." 55 His statement was duly supported by Ericsen, who had organised the ceremony (as indeed he had done for the

Uggla, 24 March 1927; “Svensk Likgiltighet för Magersfonteinminnet”, Aftonbladet, 17 May 1927.

51. “General Smuts Visits the Battlefield of Magersfontein", The Diamond Fields Advertiser, 17 December 1927.

52. “General Smuts Visits the Battlefield of Magersfontein", The Diamond Fields Advertiser, 17 December 1927.

53. The Afrikaans prayer (translated above into English) appears in Fram, "Special Magersfonten Number", February 1928, p 6, as follows: Ons dank U verder dat hier, waar 28 jaar gelede Boer en Brit in 'n doodstryd gewikkel was, sovele verteenwordigers van beide rasse mekaar vandag in die gees van vriendskap en broederskap kan ontmoet. God het in die afgelope jare ' $n$ beter verstandhouding teweeggebring; onderlinge respek en samewerking tot heil van ons vaderland het gebloei na haat en misverstand. Laat ons samesyn vandag bydra om die gees van tegemoetkoming te versterk, en elkeen aan te spoor tot hartlike en ywerige poginge in belang van die land ons almaal dierbaar.

54. "General Smuts Visits the Battlefield of Magersfontein", The Diamond Fields Advertiser, 17 December 1927; Fram, "Special Magersfontein Number”, February 1928, p 14.

55. Fram, "Special Magersfontein Number", February 1928, p 14. 
commemorative events held three years earlier). He assured Smuts and the other attendees, that:

Although immigrants from other countries are looked upon in certain circles as "Foreign Adventures" [sic] let me hasten to say that we as representatives of these small Nations are only too pleased to be able to make an honest living and and [sic] a desire to be loyal and obedient citizens of the state and true South Africans ... 56

The Scandinavians thus saw themselves as true South Africans while simultaneously maintaining and honouring their Scandinavian background - they were both, they said. ${ }^{57}$ However, Eidsvik argues that in Fram this declaration of seeing themselves as being wholly South African was outrageous. The magazine's editor urged the Scandinavians to cling to their northern lineage and honour their true heritage. ${ }^{58}$ However, it is clear that when commemorating the corps, the Scandinavians intertwined their memory with that of the wider post-war memory in South Africa.

Here, the date of the unveiling is important to note. Instead of being held on 11 December (the date of the battle at Magersfontein) the ceremony was held on 16 December (a significant day in Afrikaner history) on what was previously called the Day of the Vow or Dingaan's Day, but is now known as the Day of Reconciliation. Thus the Scandinavian commemoration was merged with a notable day of remembrance in South Africa. ${ }^{59}$ And Dingaan's Day was not just any South African holiday, as Leslie Witz points out. He explains that the day was "conceptualised as a victory of the forces of colonialism and civilisation over barbarism and heathenism". ${ }^{60}$ Liz Stanley also notes that the national symbolism of Dingaan's Day was considerably stronger during the 1920s and 30s, and that both the Women's Monument in Bloemfontein

56. Fram, "Special Magersfontein Number", February 1928, p 14.

57. Opening his address at the unveiling ceremony, Ericsen reiterated the same message: "I feel sure that I voice the feelings of every true South African that it should be our aim to forget the hardships, the strife and ravages of past wars", and saw himself as a true South African. See "General Smuts Visits the Battlefield of Magersfontein", The Diamond Fields Advertiser, 17 December 1927.

58. Eidsvik, "Expressions of Pan-Scandinavian Sentiment”, pp 139-140.

59. After the unveiling ceremony and a luncheon sponsored by mining magnate and parliamentarian, Sir Ernest Oppenheimer (who was unable to attend because of parliamentary duties) the guests celebrated Dingaan's Day. See Fram, "Special Magersfontein Number", February 1928, pp 14, 18.

60. L. Witz, Apartheid's Festival: Contesting South Africa's National Pasts (Indiana University Press, Bloomington, 2003), p 45. In the same idiom, Autry writes: "For many Afrikaners this victory [over King Dingane] confirmed that they were a chosen people - destined to rule the country and bring civilization to the land". See R.K. Autry, "The Monumental Reconstruction of Memory in South Africa: The Voortrekker Monument", Theory, Culture, Society, 29 (2012), pp 146-164, at p 149. 
and the Voortrekker Monument in Pretoria were inaugurated on 16 December. ${ }^{61}$ Coupled with the importance and meanings the day held, it was perhaps no coincidence that in his speech, Smuts also said:

\begin{abstract}
"I know ... that we are doubly rooted in the right here; and so long as we play the game by every man, by white and black; so long as [we] do justice and right [and] stand for the Christian civilisation which we have inherited from our European forebears, so long white civilisation will be safe in this country, and will flourish, and this country will become one of the historic countries of the world." [Loud applause. $]^{62}$
\end{abstract}

In the editorial of the magazine Fram, in its special Magersfontein issue, the heading reads: "Voort Magna Charta. (Omne Solum Forti Patria)". The words "Our Magna Charta" are followed by a quote from Ovid, which roughly translates as: "to the brave, every land is his [own] country". ${ }^{63}$ The chief editor wrote: "the Scandinavians out here have, through their countrymen's fight for freedom and rights, earned their Magna Charta to the soil of South Africa - a title paid with lives and sealed with blood." 64 Furthermore, he went on to proclaim that the Scandinavians should go forth to build "a house of Scandinavian loyalty" in South Africa, which in Eidsvik's analysis proves his argument of a pan-Scandinavian sentiment that was reinforced through the commemoration of the corps. ${ }^{65}$

However, Eidsvik's analysis fails to situate the editorial in a wider context, one where the theme of white racial unity in South Africa dominated the discourse and the memory of the Scandinavian Corps was used by the Scandinavians to legitimise their place within South Africa. The Scandinavian "Magna Charta" had in principle no real basis, but could nonetheless be considered a legitimate claim (within the discourse of colonialism) to the soil of South Africa. Consider, for example, the way German settlers legitimised their claim to German South West Africa: "And this land must remain German, German to its very core; it has been truly purchased dearly enough by all the noble [German] blood absorbed by its soil." 66

61. Stanley, L., 'A 'Secret History' of Local Mourning: The South African War and State Commemoration", Society in Transition, 33, 1 (2002), p 5; Autry, "The Monumental Reconstruction of Memory in South Africa", p 149.

62. “General Smuts Visits the Battlefield of Magersfontein", The Diamond Fields Advertiser, 17 December 1927.

63. Fram, "Special Magersfontein Number", February 1928, p 2; Ovid: In Six Volumes, Volume 5 (Harvard University Press, Cambridge: Mass., 1989), p 37.

64. Fram, "Special Magersfontein Number", February 1928, p 2 (translated by the author).

65. Eidsvik, "Expressions of Pan-Scandinavian Sentiment", p 140.

66. Cited in J.K. Noyes, Colonial Space: Spatiality in the Discourse of German South West Africa 1884-1915 (Harwood Academic, Chur, 1992), p 253. Noyes writes "during the Nazi reign, colonial enthusiasts repeated this same imperative as an argument for the restoration of the colonies to Germany. The land is marked with German blood, and so [the argument goes] the colonies are Germany's rightful possession." See Noyes, Colonial Space, p 257. 
As John Noyes writes: "The idea that to trace a script across a surface to mark it as a possession is a recurrent theme recognisable in various forms in the discourse of colonialism." Monuments, graves and blood constitute such a script, writes Noyes. ${ }^{67}$ It is through this symbolic purchasing power wielded by death - the lives of the fallen members of the Scandinavian Corps - that other Scandinavians, simply by virtue of belonging to the same imagined community, were able to claim their "legitimate" place as part of white settler society in South Africa. However, from the 1930s onwards the memory of the corps began to fade, not only in South Africa but in the Nordic region as well. The memory had lost its political relevance, and so too had the pan-Scandinavian sentiment espoused in the magazine Fram. According to Eidsvik, "many Scandinavians had become naturalised citizens of the Union of South Africa", and thus one might surmise that they no longer needed the memory of the corps to legitimise their place in the white community in South Africa. ${ }^{68}$

\section{Regarding race and identity}

When commemorating the Scandinavian Corps, it is evident that the South African War was portrayed at the time as a "white man's war", fought between Boer and Briton, and that the unified country born of that struggle was primarily envisaged as a white man's country. ${ }^{69}$ The complete blindness to black involvement in the war, ${ }^{70}$ and to black people in general, was not accidental but necessary in order to claim white ownership of South Africa. For example, Noyes argues that:

If it is to be shown that possession is strictly in the hands of the colonizer, discursive strategies must be developed to ensure that the marks of suffering of the colonized are obliterated, or in some way neutralized. By this I mean that the suffering of the native is either quite simply not seen, or else it is seen to be something completely different from the suffering of the settlers and soldiers. Thus the most basic strategy involved here is a blindness to the suffering of the colonized. ${ }^{71}$

In the aftermath of the war, the reconciliatory narrative of brotherhood and unity between the white races which was pursued by both Botha and Smuts,

67. Noyes, Colonial Space, p 252.

68. Eidsvik, "Expressions of Pan-Scandinavian Sentiment", p 141.

69. S. Dubow, "South Africa and South Africans: Nationalism, Belonging, Citizenship", in R. Ross, A. Kelk Mager and B. Nasson (eds), The Cambridge History of South Africa. Volume 2, 1885-1994 (Cambridge University Press, Cambridge, 2011), pp 33-34.

70. While this is certainly true of the time frame to which this article refers, note that the involvement of black people in the South African War of 1899-1902, has since the 1980 s featured in a number of academic and other publications. It is now widely accepted that all South Africans were affected by the war. This is reflected in the fact that the name Anglo-Boer War (which identifies the two major combatants) now more accurately reflects the involvement of the entire population of the country in the war.

71. Noyes, Colonial Space, p 242. 
constructed a vision of a white common identity and a white South Africa. Nasson describes this aptly as "white nationalism". ${ }^{72}$ And the Scandinavian migrants residing in South Africa seem to have bought into to this ideology. According to Eidsvik, the Scandinavianism portrayed in Fram was also coupled with a strong belief in Nordic racial superiority. The magazine's founder, Høyer, as Eidsvik points out, "encouraged immigration from northern Europe to South Africa, yet strongly discouraged Jewish migration and migration from southern Europe in general". ${ }^{73}$ And furthermore, there was an idea that they shared the same moral values with both Afrikaners and English speaking South Africans. During the celebration of Dingaan's Day after the unveiling ceremony in 1927, one commentator in Fram wrote: "Most of us were probably struck by how many similarities exist between Boers and Scandinavians - not only in appearance but also in customs and traditions."74

In the early twentieth century, the Scandinavian migrants in South Africa seem to have perceived themselves as both Scandinavian and South African, although which identity came first is a matter for debate. ${ }^{75}$ However, this sense of dual identity was not new to South Africa. Dubow notes: "W. P. Schreiner, soon to become premier of the Cape, informed the House of Commons in 1897: 'I am South African first, but I think I am English after that'."76 However, it was only through their Scandinavian identity or sense of belonging to that same imagined community, that they were able to evoke the memory of the Scandinavian Corps and give it a purpose beyond simply mourning the fallen. As Geoffrey Cubitt writes:

To evoke a collective past is always to annex earlier experiences to a present social conception, and the language of collective memory tends to obscure the extent to which the perceived relevance of such a past to today's social identities must always be an imaginative or ideological construction. ${ }^{77}$

72. Nasson, The Boer War, pp 288-289, 294. See also Dubow, "South Africa and South Africans", p 33.

73. Eidsvik, "Expressions of Pan-Scandinavian Sentiment", p 140.

74. Fram, "Special Magersfontein Number", February 1928, p 18 (translated by the author). During the South African War there was evidence of "Boer romanticism" among certain conservatives in Sweden. In Aftonbladet the Boers were even likened to "Dalkarlar" (i.e. rural farmers who had fought alongside Gustav Vasa, who is perceived as the founding father of modern day Sweden). According to Jan-Gunnar Rosenblad this romanticism of the Boers can be seen as a metaphor for Swedish nationalism and its ideal of the old rural farmer. See, for example, "Det Sydafrikanska Krigets Växlingar", Aftonbladet, 28 October 1899; and J-G. Rosenblad, Nation, Nationalism och Identitet: Sydafrika i Svensk Sekelskiftesdebatt (Nya Doxa, University Nora, Stockholm, 1992), pp 159-161.

75. There is no mention of the Scandinavians' citizenship status in the sources, although there is some indication that at least some of them attained citizenship. Ericsen, for example, was said to have served in the local council in Kimberley and even functioned as its mayor. See Fram, "Special Magersfontein Number", February 1928, p 18.

76. Dubow, "South Africa and South Africans", p 31.

77. G. Cubitt, History and Memory (Manchester University Press, Manchester, 2007), p 17. 
During the 1920s, the Scandinavians were especially eager to declare their loyalty to South Africa and come across as true South Africans, or as one of the Scandinavians put it (while also pointing out that many Scandinavians had also fought alongside the British during the South African War): "The Scandinavians ... are always loyal to the Flag under which they live. Now when we have got our New South African Flag we will respect [it the] same and be true to it."78 However, in the 1930s, it seems that the Scandinavians wholly embraced their South African identity and in turn forgot the corps that had given them their symbolic "Magna Charta".

\section{Concluding remarks}

When looking back at the commemoration of the Scandinavian Corps in South Africa, and among the Scandinavian migrants in particular, one notices the different shifts in its history - from despised and disdained; to honoured and celebrated; and then to a faded and forgotten memory.

The memory of the Scandinavian Corps was only embraced by the Scandinavian migrants when it legitimised the Scandinavian presence in South Africa. It is therefore somewhat ironic that it was thanks to the funding from the Scandinavian countries - Sweden in particular, that the monuments could even be erected. The pan-Scandinavian sentiment which, at least in part, motivated this commemoration of the corps in the "mother countries" was also mirrored in South Africa. But in Eidsvik's analysis, Scandinavianism or pan-Scandinavian sentiment was primarily promoted in the magazine Fram and through its reporting of the commemoration of the Scandinavian Corps seems, in his view, almost exclusive to the Scandinavian population in South Africa. He writes:

Indeed, Fram stands out as an example of Scandinavianism constructed and expressed as late as the 1920s and 1930s, a half-century after the period in which the movement flourished in Scandinavia ...79

However, he also claims that pan-Scandinavian efforts in the Nordic region were expressed in Fram and that this "confirmed that Scandinavianism was still vibrant in the mother countries". ${ }^{80}$ The commemorative events honouring the Scandinavian Corps which were held in Scandinavia during 1924 prove that Scandinavianism was not only present in Scandinavia, but was perhaps articulated even more in Scandinavia than in South Africa. And the key notion when the corps was commemorated in South Africa was not primarily to promote the idea of Scandinavian unity or pan-Scandinavian sentiment among the Scandinavian migrants in South Africa. Instead the purpose, as has been shown above, was to promote "white nationalism" in South Africa. Indeed, what stands out is that the memory was in no way an exclusive issue - instead it is situated in a far wider context of post-war

78. Fram, "Special Magersfontein Number", February 1928, p 17.

79. Eidsvik, "Expressions of Pan-Scandinavian Sentiment", p 135.

80. Eidsvik, "Expressions of Pan-Scandinavian Sentiment", p 139. 
memory politics in South Africa, where the memory was closely intertwined with the reconciliatory narrative of brotherhood and unity between the white races in South Africa that was being actively encouraged by members of the Afrikaner elite. (It is noteworthy that both monuments were unveiled by future or former premiers of the Union of South Africa, namely Botha and Smuts). Therefore, one might claim that the memory was hijacked by the Afrikaners, who also formed the majority of the attendees at these commemorative events. But it is also true that the Scandinavians requested the old Boer generals - by then the Afrikaner elite - to unveil the monuments of their fallen. And while initially the Scandinavians had played the part of extras in this reconciliatory narrative, they eventually subscribed to this racialized ideology of a white common identity, and in turn expressed this sentiment with a similar rhetoric during the commemorative events in the 1920s, where they even claimed to speak as true South Africans.

The Scandinavian Corps and the battle fought at Magersfontein was seen as the Scandinavians' very own "Magna Charta", their title to the soil of South Africa, a right they had paid for with their lives and their blood. However, when they no longer had need of this claim to legitimise their place in South Africa, when they had become true South Africans, the memory of the Scandinavian Corps faded and was soon forgotten. The monuments were left to wither on the now desolate fields of Magersfontein. ${ }^{81}$ But the epitaph, emblematic of the heroic narrative constructed around the corps and its battle, can still be discerned today:

De kunde icke vika, blott falla kunde de

(They could not retreat, they could only fall)

81. It is interesting that the monuments were placed where very few saw them or took the trouble to visit them. The maintenance of the monuments was gradually neglected. On this Noyes argues: "Now, if we consider that a tombstone is normally intended as a display; that is, a sign to be pondered over, with an inscription to be read, we may be struck here by a certain contradiction. When discussing the cost of maintaining the graves, it is constantly mentioned that many of them are 'far from the lines of transportation.' In other words, they will almost never be seen by any 'white eyes', except those responsible for the maintenance itself. A paradox? Not if we recognize that the marking of the ground with tombstones is a writing in the most profound sense - its meaning is intended first for the one who writes, and second for the transcendental eye, which is also the position to which the meaning of death accrues". See Noyes, Colonial Space, pp 254-255. With regard to the issue of decaying/withering, some sources in the late 1950s and 1960s, complained about the sorry state of the Scandinavian monuments. One even claimed that the inscriptions had faded and could not be read. See KrA, SKA: Volume 3, Letter from Börje Furtenbach to Hjalmar Uggla [the son of Christer Uggla], 5 December 1958; and J. Cronstedt, "Magersfontein: Gemensam Nordisk Hjälteinsats i Boerkriget", Vägen Framåt, 11, 12 (1968), p 10. 


\section{REFERENCES}

Autry, R.K., "The Monumental Reconstruction of Memory in South Africa: The Voortrekker Monument", Theory, Culture, Society, 29 (2012), pp 146-164.

Carlsson, A.G., “Norske Reaksjoner på Boerkrigen 1899-1902: En Analyse av Norske Advisers Holdninger og en Beskrivelse av Norsk Engasjement, Inkludert Nordmenn i Sør-Afrika", MA dissertation, University of Trondheim, 1978.

Cronstedt, "Magersfontein: Gemensam Nordisk Hjälteinsats i Boerkriget", Vägen Framåt, 11, 12 (1968).

Cubitt, G., History and Memory (Manchester University Press, Manchester, 2007).

Dubow, S., "South Africa and South Africans: Nationalism, Belonging, Citizenship", in Ross, R., Kelk Mager, A. and Nasson, B. (eds), The Cambridge History of South Africa, Volume 2, 1885-1994 (Cambridge University Press, Cambridge, 2011).

Eidsvik, E., "Expressions of Pan-Scandinavian Sentiment in the Magazine Fram among Scandinavian Migrants in South Africa, 1914-54", in Harvard, J. and Stadius, P. (eds), Communicating the North: Media Structures and Images in the Making of the Nordic Region (Ashgate, Burlington, 2013).

Eidsvik, E., Spaces of Scandinavian Encounters in Colonial South Africa: Reconfiguring Colonial Discourses (University of Bergen Press, Bergen, 2013).

Eklund, S.O., "The Scandinavians and the Boer War", South Africa International, 10 (1980).

Hale, F., "The Scandinavian Corps in the Second Anglo-Boer War", Historia, 45, 1 (2000), pp 220-236.

Janek, H.P., Bland Boer och Britter: Skildringar från Kriget i Sydafrika, 1898-1900: med 16 Illustr. efter Fotografier (Schmidts Boktr., Helsingborg, 1901).

McFarland, E.W., "Commemoration of the South African War in Scotland, 1900-10", The Scottish Historical Review, 89, 2 (October 2010), pp 194-223.

Meijer, B. (ed.), Nordisk Familjebok: Konversations Lexikon och Realencyklopedi (Nordisk Familjeboks Förlag, Stockholm, 1904).

Mossberg, E., Minnen Från Tre Krig och Från Krig i Fred (Bonnier, Stockholm, 1943).

Nasson, B., "The South African War/Anglo-Boer War 1899-1902 and Political Memory in South Africa", in Ashplant, T.G., Dawson, G. and Roper, M. (eds), Commemorating War: The Politics of Memory (Transaction Publishers, New Brunswick: NJ, 2004).

Nasson, B., The Boer War: The Struggle for South Africa (History Press, Stroud, 2011).

Nordmann, P. (ed.), Boerer och Engelsmän: Skildringar ur det Sydafrikanska Kriget, 1899-1901. Av Österbottningarna Matts Gustavsson, Nils Viklund m.fl. Medlemmar av den Skandinaviska Kåren (Svenska folkskolans vännner, Helsingfors, 1910). 
Noyes, J.K., Colonial Space: Spatiality in the Discourse of German South West Africa 1884-1915 (Harwood Academic Publishers, Chur, 1992).

Näsström, B-M., Nordiska Gudinnor: Nytolkningar av den Förkristna Mytologin (Bonnier, Stockholm, 2009).

Olin, K-G., Afrikafeber (Olimex, Jakobstad, 2000).

Ovid: In Six Volumes, Volume 5 (Harvard University Press, Cambridge: Mass., 1989).

Rosenblad, J-G., Nation, Nationalism och Identitet: Sydafrika i Svensk Sekelskiftesdebatt (Nya Doxa, University Nora, Stockholm, 1992).

Stanley, L., "A 'Secret History' of Local Mourning: The South African War and State Commemoration", Society in Transition, 33, 1 (2002), pp 1-25.

Uddgren, H.E. Hjältarna vid Magersfontein: en Skildring av den Skandinaviska Kårens och Ambulansens Öden och Äventyr [Minnesskrift] (Seelig, Stockholm, 1924).

Uggla, C. Redogörelse över Magersfontein Minnesfesternas Ändamål och Resultat: 189911 Dec. 1924 (Almqvist \& Wiksell, Uppsala, 1926).

Uola, M., "Finnish Warriors in the South African War", Siirtolaisuus-Migration, 1 (1977), pp 2-13.

Westrin, T. (ed.), Nordisk Familjebok: Konversations Lexikon och Realencyklopedi (Nordisk Familjeboks Förlag, Stockholm, 1917).

Winquist, A., Scandinavians and South Africa: Their Impact on the Cultural, Social and Economic Development of pre-1902 South Africa (Balkema, Cape Town, 1978).

Witz, L., Apartheid's Festival: Contesting South Africa's National Pasts (Indiana University Press, Bloomington, 2003). 